\title{
Geotechnical Investigation for Foundation Design at the West Bank of Light House Creek, Lagos Deep Offshore Logistics Free Zone, Nigeria
}

\author{
Nwankwoala H. O. ${ }^{1}$ \\ ${ }^{1}$ Deparrment of Geology, University of Port Harcourt, Nigeria \\ Correspondence: Nwankwoala H. O., Deparrment of Geology, University of Port Harcourt, Nigeria. E-mail: \\ nwankwoala_ho@yahoo.com
}

Received: March 15, 2019

Accepted: May 5, 2019 Online Published: May 7, 2019

doi:10.5539/emr.v8n1p31

URL: https://doi.org/10.5539/emr.v8n1p31

\begin{abstract}
This study is aimed at investigation for foundation designs at the West Bank Creek, Lagos deep offshore. All field tests were conducted in accordance with standard geotechnical procedure. The soil profiles obtained within the depth explored at the site consist essentially of two soil zones. They are very soft silty clays and medium dense sands. Results revealed that within the depths bored, a relatively high deposit of clay overlies the boreholes from the river-bed to average depth of $3.0 \mathrm{~m}$. In BHs 8, 10,11 and 12, the clay extends beyond 3.0m thickness with varying depths ranging from $5.0 \mathrm{~m}$ to $8.0 \mathrm{~m}$. However, prevalent deposits of sand underlie the clay to the end of the boreholes. In BHs 6 and 9, the entire holes are characterized by huge deposits of sand formation. Notably, the sandy formation exhibited appreciable Standard Penetration Test (SPT) blows indicating sands of medium densification. Based on the field investigations and comprehensive studies, the estimated volume of available sand fill material is $691,863 \mathrm{~m}^{3}$. Sand volume estimate was limited to $-10.50 \mathrm{~m}$ from the river-bed. All the boreholes have potentials for sand borrows. Scooping of the clayey materials is required to expose the sand deposits. Dredging operation with appropriate dredger should be limited to the area covered by the survey.
\end{abstract}

Keywords: sub-soil, sub-sea sediments, foundation, geotechnical, boreholes, offshore, Lagos deep offshore logistics free zone

\section{Introduction}

Geotechnical site investigation involves among others, the need to assess the general suitability, safety and economical design of foundations and temporary works, knowing the nature of each stratum and engineering properties of the soil and rock as well as foresee and provide solutions against difficulties that may arise during construction due to ground conditions (Bolton, 1981; Braja, 2005; Clayton et al., 1996). Several studies regarding the geotechnical properties of foundation soils in the creek area of southwestern Nigeria have also been carried out by some researchers. Adepelumi and Olorunfemi (2000) established the geological/geo-electrical sequence of the reclaimed Lekki Peninsula, Lagos, Nigeria. They identified certain sand columns whose thicknesses revealed the geomorphological features of the original pre-fill terrain. Oyedele and Olorode (2010) investigated the prevalent subsurface geological conditions responsible for differential settlement of various degrees peculiar to structures at Medina Estate, Gbagada, Lagos. Their study revealed that the area is underlain to a depth of $14 \mathrm{~m}$ by Recent Lithoral Alluvium and Coastal Plain Sands of the Dahomey Basin. It was discovered that foundation soils at shallow depths consist of an extensive layer of materials with extremely low shear strength and corresponding high volume of compressibility.

The complexity of a site investigation depends upon the nature of the ground conditions and the type of engineering structure (Bell, 1990; 2011). Accordingly, a site investigation should attempt to foresee and provide against difficulties that may arise during construction because of ground and/or local conditions. Such investigations should reveal the strata that would be significantly affected by the structural load, the groundwater condition, the degree and extent of weathering, the structural orientation of the rock masses is equally important (Adepelumi et al., 2009; Lekmang et al., 2016). Foundation studies usually provide subsurface information that aid in the design of structures (Warmate \& Nwankwoala, 2018). It is thus useful to understand the geotechnical 
properties of the soil material (index and engineering) so as to make use of the materials in ways that they are best suited since the geotechnical properties of soils, to a large extent determine its suitability for various purposes (Johnson \& Degraff, 1988; Ejembi, 2016; Ameh et al., 2018). It is in this regard, that the sub-surface geotechnical investigation of the need to evacuate any existing debris or wrecks from the river bed, deepen the river channel and ascertain the underlying soil along the Light House Creek to ensure stability of the existing quays and foundation designs to support proposed jetty and future structures led to the geotechnical investigations. The information regarding detailed characterization of foundation soils, as well as geotechnical properties of moisture-prone clay in the composition of the soils are scanty. The study area therefore, is a fast growing and future Free Trade Zone which offers great opportunities for infrastructural development. This study intends to characterize the foundation soils, and investigate response of the moisture-prone clay component of the foundation soils to structural loads. The study also aims at carrying out particle size distribution analyses for engineering soil classifications as well as the determination of the bearing capacity and settlement rates necessary for foundation design of structures. The data generated and analyzed will help in ascertaining the suitability of the site for future infrastructural development.

\section{Geology of the Area/Accessibility}

The area (Figure 1) falls within the geographical setting of Lagos and Dahomean Embayment which consist of the alluvial deposits of South Western Nigerian basin. Lagos is underlain by the Benin Basin. The rocks of the Benin Basin are mainly sands and shales with some limestone which thicken towards the west and the coast as well as down dips to the coast (Oteri \& Atolagbe, 2003). Five litho-stratigraphic formations covering the cretaceous to Tertiary ages have been described to be prominent in this geological belt. The formations from the oldest to the youngest include: Abeokuta Group (Cretaceous), Ewekoro Formation (Paleocene), Akinbo Formation (Late Paleocene-Early Eocene), Oshosun Formation (Eocene) and llaro Formation (Eocene) (Adeyemi \& Osammor, 2000). The Abeokuta Group presents an unconformity with the basement complex. Locally, the superficial deposits of the area are made up of coastal plain characterized by sand bars, lagoons and creeks (Adegoke et al., 1980). It should be noted however that the recent coastal deposits which occur widely in Lagos State includes the tertiary beds from the Benin Formation which stretches from Calabar in the east through Lagos state to the borders of Benin Republic in the west (Kogbe et al., 1983). Access to the site is generally by water transport. The site could be accessed via the Liverpool Jetty or Coconut Jetty along Apapa-Oshodi Expressway, Lagos.

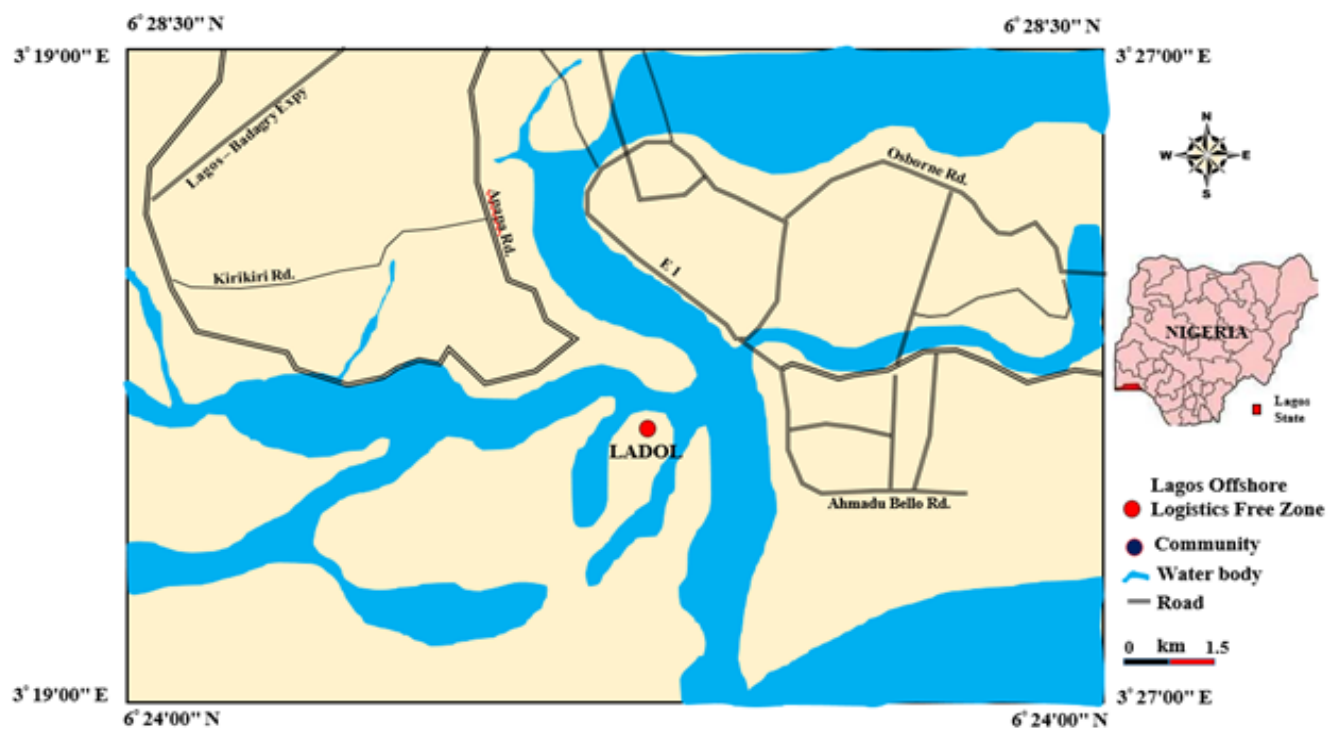

Figure 1. Map showing study location

\section{Methods of Study}

This involves 12 nos Electric Dutch Cone Penetration Test (CPTu) to refusal and 12 nos random sampling of river-bed sediments. The boreholes were drilled by the shell and auger cable percussive drilling method. The rig positioned on a floating element was fitted with a free fall auger. The auger was lifted to a height of about $1.0 \mathrm{~m}$ 
above ground level, and allowed to free-fall under gravity to advance the boring. As the auger falls, it cuts through the soil such that the cut soil material is retained inside it by means of a clerk. The auger is then brought to the surface where the soil retained in it is emptied out. To prevent collapse of the borehole wall, the holes were lined with casings or shell corresponding to the size of the auger being used for the drilling. As the drilling continues, the auger drops into the open hole until the time sample is to be taken. 4 inch American Petroleum Institute (API) casing strings were for the soil coring.

Representative undisturbed and disturbed samples were taken at regular intervals of $1.00 \mathrm{~m}$ depth or where there is change in soil strata. The samples were used for a detailed and systematic description of the soil in each stratum in terms of its visual properties and for laboratory analysis. Undisturbed samples were recovered from the cohesive layers by driving a $100 \mathrm{~mm}$ diameter sampler (U2) through a total distance of $450 \mathrm{~mm}$.

Standard Penetration Test (NSPT) was carried out at $3.0 \mathrm{~m}$ interval on granular formation. A $50 \mathrm{~mm}$ diameter split spoon sampler is driven $450 \mathrm{~mm}$ into the soil using a $63.5 \mathrm{~kg}$ hammer with a $760 \mathrm{~mm}$ drop. The penetration resistance is expressed as the number of blows ( $\mathrm{N}$-value) required to obtain $300 \mathrm{~mm}$ penetration below an initial $150 \mathrm{~mm}$ penetration through any disturbed ground at the bottom of the borehole

\subsection{Cone Penetration Tests}

Electric Cone Penetrometer of $100 \mathrm{KN}$ capacity was used in the cone resistance soundings. The equipment consists of CPT mainframe, Piezo-Cone, Depth encoder, Transducer and enabling software for data capture. Continuous sounding procedure was adopted in the test. The cone was first forced into the ground a distance of $10 \mathrm{~cm}$ by the application of force to the outer sounding tubes. The cone is then pushed out a distance of about $4 \mathrm{~cm}$ by the application of force and the magnitude of the force required to achieve this, is transmitted via the transducer to the computer system.

The principal feature of the cone penetrometer is that the tip resistance to penetration by the cone (Sanglerat, 1972), the sleeve friction resistance, pore-water pressure and friction ratio were assessed independently during the study. Importantly, these parameters were color-coded for identification. The tip resistance denoted as Qc was measured by the load cell. The sleeve friction resistance, fs is measured by tension load cell embedded in the sleeve. The friction ratio, $\mathrm{Rf}$ is the ratio of the skin friction divided by the tip resistance and the in-situ pore-water pressure measures the pore stress in relation to water in the void spaces within the soil.

\subsection{Sub-sea Sediment Sampling}

Sediment samplings were collected randomly from the river-bed. The Vaan Veer Grab was fitted to the tripod rig and lowered into the river. Prior to lowering the Grab into river, the sample compartment was opened by suspending the control lever in an upward thrust position. The weight of the grab serves as dead-load. Upon pulling the sling of the tripod rig, the control lever is forcefully released and the sample compartment initially opened drops to the river-bed. As the sling is pulled up by means of winding the handle of the tripod rig, the sample compartment closes and the retained sediment is prevented from dropping off. The soil boring and Cone Penetration test were coordinated prior to the testing. Table 1 below presents the coordinates of the boreholes and the CPTs.

Table 1. Coordinates of boreholes

\begin{tabular}{llll}
\hline S/No. & BH/CPT & Easting & Northing \\
\hline 1 & BH/CPT-1 & 543355 & 710878 \\
2 & BH/CPT-2 & 543467 & 710869 \\
3 & BH/CPT-3 & 543355 & 710772 \\
4 & BH/CPT-4 & 543466 & 710771 \\
5 & BH/CPT-5 & 543408 & 710695 \\
6 & BH/CPT-6 & 543297 & 710693 \\
7 & BH/CPT-7 & 543354 & 710613 \\
8 & BH/CPT- & 543461 & 710615 \\
9 & BH/CPT-9 & 543403 & 710534 \\
10 & $\mathrm{BH} /$ CPT-10 & 543293 & 710537 \\
11 & BH/CPT-11 & 543356 & 710454 \\
12 & BH/CPT-12 & 543456 & 710456 \\
\hline
\end{tabular}


The following laboratory tests were performed on the soil samples:

1) Classification Tests: These will be carried out on both disturbed and undisturbed samples and include but not limited to the determination of natural moisture contents, Atterberg Limit, Sieve Analysis and Unit Weights.

2) Soil Strength Tests: These involve essentially the determination of the relevant strength parameters of cohesion-less samples such as Undrained Unconsolidated Triaxial Tests.

3) Compressibility Tests: This involves the determination of the compressive properties of the soil such as one-dimensional oedometer.

4) Sediment Analysis: This involves determination of chemical properties of the sub-sea sediment in accordance with EGASPIN. The parameters are pH, Conductivity, TPH, TOC, Sulphate, Cation Exchange Capacity, TCC, THC, Nitrate and Phosphate.

\subsection{Moisture Content}

The water content was determined by drying selected moist/wet soil material for at least 6 hours to a constant mass in a $110^{\circ} \mathrm{C}$ drying oven. The difference in mass before and after drying was used as the mass of the water in the test material. The mass of material remaining after drying was used as the mass of the solid particles. The ratio of the mass of water to the measured mass of solid particles was the water content of the material. This ratio can exceed 1 (or $100 \%$ ).

\subsection{Atterberg Limits}

Atterberg limits were determined on soil specimens with a particle size of less than $0.425 \mathrm{~mm}$. The Atterberg limits refer to arbitrary defined boundaries between the liquid limit and plastic states (Liquid Limit, WL), and between the plastic and brittle states (Plastic Limit, Wp) of fine-grained soils. They are expressed as water content, in percent.

The liquid limit is the water content at which a part of soil placed in a standard cup and cut by a groove of standard dimensions flow together at the base of the groove, when the cup is subjected to 25 standard shocks (Casagrande, 1932). The one-point liquid test was carried out. Distilled water was added during soil mixing to achieve the required consistency.

The plastic limit is the water content at which a soil can no longer be deformed by rolling into $3 \mathrm{~mm}$ diameter threads without crumbling. The range of water contents over which a soil behaves plastically is the Plasticity Index, Ip. This is the difference between the liquid limit and the plasticity limit (WL-WP).

\subsection{Particle Size Analyses}

Particle size analyses were performed by means of sieving and/or hydrometer readings. Sieving was carried out for particles that would be retained on a $0.075 \mathrm{~mm}$ sieve, while additional hydrometer readings were carried out when a significant fraction of the material passes a $0.075 \mathrm{~mm}$ sieve. Dry sieving was carried out by passing the soil sample over a set of standard sieve sizes and then shakes the entire units for few minutes with sieve shaker (machine). Particle size is presented on a logarithmic scale so that two soils having the same degree of uniformity are represented by curves of the same shape regardless of their positions on the particle size distribution plot. The general slope of the distribution curve may be described by the coefficient of uniformity $\mathrm{Cu}$, where $\mathrm{Cu}=\mathrm{D} 60 / \mathrm{D} 10$, and the coefficient of curvature $\mathrm{Cc}$, where $\mathrm{Cc}=(\mathrm{D} 30)^{2} / \mathrm{D} 10 \times \mathrm{D} 60 . \mathrm{D} 60, \mathrm{D} 30$ and D10 are effective particle sizes indicating that $60 \%, 30 \%$ and $10 \%$ respectively of the particles (by weight) are smaller than the given effective size.

\subsection{Unit Weight}

The unit weights were determined from measurements of mass and volume of the soil. The unit weight $\mathrm{g}\left(\mathrm{KN} / \mathrm{m}^{3}\right)$ refers to the unit weight of the soil at the sampled water content. The dry unit weight gd, was determined from the mass of oven-dried soil and the initial volume.

\subsection{Undrained Shear Strength}

This test was performed on relatively undisturbed cohesive soils. Depending on the consistency of the cohesive material, the test specimen was prepared by trimming the sample or by pushing a mould into the sample. A latex membrane with thickness of approximately $0.2 \mathrm{~mm}$ was placed around the specimen. A lateral confining pressure of $25 \mathrm{KPa}$ to $100 \mathrm{KPa}$ is maintained during axial compression loading of the specimen. Consolidation and drainage of pore water during testing is not allowed. The test is deformation controlled (strain rate of $60 \% / \mathrm{h}$ ), single stage, and stopped when an axial strain of $15 \%$ is achieved. The deviator stress is calculated from the measured load assuming that the specimen deforms as a right cylinder. The presentation of test results includes a 
plot of deviator stress versus axial strain. The Undrained shear strength, $\mathrm{Cu}$, is taken as half the maximum deviator stress. When a maximum stress has not been reached at strains of less than $15 \%$, the stress at $15 \%$ strain is used to calculate undrained shear strength.

\subsection{Consolidation}

The one-dimensional consolidation referred to Oedometer is performed in a Consolidometer. Clayey soil specimen usually of $63.5 \mathrm{~mm}$ in diameter and $25.4 \mathrm{~mm}$ thick is placed inside a metal ring with two porous stones, one at the top of the specimen and another at the bottom. The load on the specimen is applied through a lever arm, and compression is measured by a micrometer dial gauge. The metal ring containing the soil specimen is saturated throughout the duration of the test. Each load is usually kept for 24 hrs expect where the compression values becomes insignificant. At the end of the test, the dry weight of the test specimen is determined.

Three basic principles of the test are identified. First, the initial compression which defines the pre-loading stage of the specimen, the second is the primary consolidation where excess pore-water pressure is gradually transferred in effective stress by the expulsion of pore-water. The third principle is the secondary consolidation which occurs after dissipation of the excess pore-water pressure, when some deformation of the specimen takes place because of the plastic readjustment of the soil fabric.

The plot of void ratio (e) against effective pressure (P) for the samples tested, together with calculated values of the coefficients of consolidation $(\mathrm{Cv})$ and of the coefficients of compressibility $(\mathrm{Mv})$. All laboratory tests were carried out in accordance with B.S. 1377 (1995) - Methods of Tests for Soil for Civil Engineering Purposes.

\subsection{Engineering Properties of the Soil}

The soil profiles obtained within the depth explored at the site consist essentially of two soil zones. They are very soft silty clays and medium dense sands. The geotechnical indexes and engineering parameters of the soil are presented in the Tables $2 \mathrm{a}$ and $2 \mathrm{~b}$ below:

Table 2a. Very soft silty clays

\begin{tabular}{ll}
\hline Test Parameter & Average \\
\hline Moisture Content (\%) & 59 \\
Liquid Limit (\%) & 67 \\
Plastic Limit (\%) & 35 \\
Plastic Limit (\%) & 32 \\
Plastic Limit (\%) & 0.76 \\
Plastic Limit (\%) & 16.08 \\
Plastic Limit (\%) & 10.41 \\
Plastic Limit (\%) & 21 \\
\hline
\end{tabular}

Table $2 \mathrm{~b}$. Fine sand

\begin{tabular}{ll}
\hline Test Parameter & Average \\
\hline D10 Effective Diameter (mm) & 0.09 \\
D30 & 0.18 \\
D60 & 0.37 \\
Co-efficient of Uniformity (Cu) & 4.05 \\
Co-efficient of Curvature (Cc) & 1.00 \\
Co-efficient of Permeability (K) $\mathrm{m} / \mathrm{sec}$ & $6.37 \times 10^{-4}$ \\
Angle of Internal friction (f) & 35 \\
Bulk Unit Weight $\left(\mathrm{KN} / \mathrm{m}^{3}\right)$ & 12.47 \\
Moisture Content $(\%)$ & 20.2 \\
\hline
\end{tabular}

\section{Discussion of Results}

The investigations/study was carried out for the deepening of the Light House Creek, stability for existing quays 
and for proposed jetty and future structures. The scope of the investigations were 12 nos of soil boring to considerable depths of $-15.0 \mathrm{~m}$ from the river bed, 12 nos Electric Cone Penetration Test to refusal and 12 nos random sampling of sub-sea sediments. The site stratigraphy showed very soft dark grey silty clayey formation overlying prevalent granular formation of medium densification. Thicknesses of the overlying clayey formation vary from $2.0 \mathrm{~m}$ to $7.0 \mathrm{~m}$ and the sand extends thereafter to the end of the boring at $15.0 \mathrm{~m}$.

\subsection{Dredging Considerations}

The relevant information obtained from the borrow pits show that the area is underlain by prevalent medium sand mix underlying clayey over-burden. The sand layers occur above the maximum dredging depth of $-15.0 \mathrm{~m}$ with significant thickness to satisfy maximum requirements. BHs 1 to 7 are underlain by shallow deposits of soft clays with average depth of $3.0 \mathrm{~m}$. The clays are further underlain by sands to $15.0 \mathrm{~m}$. BH-6 is characterized entirely by sand. BHs 8 to 12 are underlain by high deposits of clays averaged $6.0 \mathrm{~m}$; its further prevails with sands to a greater height. The sands are uniformly-graded fine to medium.

Generally, burrows have potentials but requires scooping the overlying clayey formation to get to the sandy materials. Estimate of the volume of natural geologic material is computed with some degree of simplifications and approximation of actual field conditions. For simplicity, 3 basic parameters were used to determine the volume estimate. They are the length and width of the borehole spacing and depth of exploration (thickness). The conservative values of these dimensions are intentionally chosen to avoid over estimation.

Table 3. Volume estimate of natural geologic materials

\begin{tabular}{llllll}
\hline BH No. & Length & Width & Thickness & $\begin{array}{l}\text { Total Vol. } \\
\mathrm{cm}^{3}\end{array}$ & $\begin{array}{l}\text { Vol. of solid Sand } \\
\mathrm{cm}^{3}\end{array}$ \\
\hline BH-1 & $100 \mathrm{~m}$ & $100 \mathrm{~m}$ & $7.50 \mathrm{~m}$ & 75,000 & 60,975 \\
BH-2 & $100 \mathrm{~m}$ & $100 \mathrm{~m}$ & $7.50 \mathrm{~m}$ & 75,000 & 60,975 \\
BH-3 & $100 \mathrm{~m}$ & $100 \mathrm{~m}$ & $8.50 \mathrm{~m}$ & 85,000 & 69,105 \\
BH-4 & $100 \mathrm{~m}$ & $100 \mathrm{~m}$ & $7.50 \mathrm{~m}$ & 75,000 & 60,975 \\
BH-5 & $100 \mathrm{~m}$ & $100 \mathrm{~m}$ & $7.50 \mathrm{~m}$ & 75,000 & 60,975 \\
BH-6 & $100 \mathrm{~m}$ & $100 \mathrm{~m}$ & $10.5 \mathrm{~m}$ & 100,500 & $81,706.5$ \\
BH-7 & $100 \mathrm{~m}$ & $100 \mathrm{~m}$ & $7.50 \mathrm{~m}$ & 75,000 & 60,975 \\
BH-8 & $100 \mathrm{~m}$ & $100 \mathrm{~m}$ & $5.50 \mathrm{~m}$ & 55,000 & 44,715 \\
BH-9 & $100 \mathrm{~m}$ & $100 \mathrm{~m}$ & $10.5 \mathrm{~m}$ & 100,500 & $81,706.5$ \\
BH-10 & $100 \mathrm{~m}$ & $100 \mathrm{~m}$ & $4.50 \mathrm{~m}$ & 45,000 & 36,585 \\
BH-11 & $100 \mathrm{~m}$ & $100 \mathrm{~m}$ & $3.50 \mathrm{~m}$ & 35,000 & 28,455 \\
BH-12 & $100 \mathrm{~m}$ & $100 \mathrm{~m}$ & $5.50 \mathrm{~m}$ & 55,000 & 44,715 \\
Estimated Sand Volume & & & & 691,863 \\
\hline
\end{tabular}

\subsection{Piled Foundation}

Foundation to support the proposed jetty shall be on piles. Estimate for pile load capacity is based on Terzaghi's $(1943$; 1967) formula expressed below: Pile design details for reinforced cased piles are based on the cautious estimates as given below in accordance with $\mathrm{EN}-1997-2 . \mathrm{Cu}=21, \gamma$ clayey $=16.02 \mathrm{KN} / \mathrm{m}^{3}, \mathrm{f}=35^{\circ}, \mathrm{Nq}=33.30$, $\gamma$ sand $=12.47 \mathrm{KN} / \mathrm{m}^{3}$

$\mathrm{Qu}=\mathrm{qpuAb}+\mathrm{fs} \mathrm{As}$

Where

$\mathrm{Qu}=$ Ultimate bearing capacity

$\mathrm{Qpu}=\quad$ Point load capacity

$\mathrm{Ab}=$ Sectional area of the pile at its base

$\mathrm{Fs}=$ Unit skin friction resistance

As $=$ Surface area of the pile in contact with the soil 
$\mathrm{Qa}=$ Allowable bearing capacity (using factor of safety of 2.5)

For $450 \mathrm{~mm}$ Piles

i. Clayey Stratum:

Skin friction resistance for the peat $=\alpha$.Cu.As

For $450 \mathrm{~mm}$ piles: $0.75 \times 21 \times 0.45 \times \pi \times 5.0 \mathrm{~m}=111 \mathrm{~N}$

ii. Lower Sand Stratum

$\sigma$ at the top of sand stratum $16.08 \times 5.0 \mathrm{~m}=\quad 80.4 \mathrm{~N} / \mathrm{m}^{2}$

$\sigma$ at the tip of the pile $\quad 80.4+(12.47-9.81) \times 10.0 \mathrm{~m}=107 \mathrm{KN} / \mathrm{m}^{2}$

$\Sigma$ ave $=(80.4+107) / 2=93.7 \mathrm{KN} / \mathrm{m}^{2}$

Angle of internal friction (for sand) fo $=35 \mathrm{o}$, Hence

$\mathrm{fs}(\mathrm{av})=93.7 \times \tan 35 \mathrm{o}$

$=65.6 \mathrm{KN} / \mathrm{m}^{2}$

Skin friction resistances for the sand layer:

$65.6 \times \pi \times 0.45$ dia. $\times 10.0 \mathrm{~m}=927.7 \mathrm{KN}$

Total skin friction (Qs) for $450 \mathrm{~mm}$ diameter pile is:

$(111+927.7)=1,038.7 \mathrm{KN}$

Point Load Capacity

$\sigma$ at tip of pile $=93.7 \mathrm{KN} / \mathrm{m}^{2}$

$\mathrm{Nq}=33.30$ (Terzaghi's shape and depth factor 1943)

$\mathrm{Qpu}=93.7 \times 33.30=3,120 \mathrm{KN} / \mathrm{m}^{2}$

The limit of maximum value of unit point resistance in sands is $11,000 \mathrm{KN} / \mathrm{m}^{2}$. Hence, the estimated value will be used.

$3,120 \times \pi \times 0.452 / 4=496.3 \mathrm{KN}$

Ultimate Pile load capacity $\quad \mathrm{Qu}=1,038.7+496.3=1,535 \mathrm{KN}$

Allowable pile load capacity $\mathrm{Qa}=\mathrm{Qu} / 2.5=614 \mathrm{KN}$

For $600 \mathrm{~mm}$ Piles

iii. Clayey Stratum:

Skin friction resistance for the peat $=\alpha$.Cu.As

For $600 \mathrm{~mm}$ piles: $0.75 \times 21 \times 0.60 \times \pi \times 5.0 \mathrm{~m}=148.5 \mathrm{KN}$

iv. Lower Sand Stratum

$\sigma$ at the top of sand stratum $16.08 \times 5.0 \mathrm{~m}=\quad 80.4 \mathrm{~N} / \mathrm{m}^{2}$

$\sigma$ at the tip of the pile $\quad 80.4+(12.47-9.81) \times 10.0 \mathrm{~m}=107 \mathrm{KN} / \mathrm{m}^{2}$

$\Sigma$ ave $=(80.4+107) / 2=93.7 \mathrm{KN} / \mathrm{m}^{2}$

Angle of internal friction (for sand) fo $=350$, Hence

$\mathrm{fs}(\mathrm{av})=93.7 \times \tan 35 \mathrm{o}$

$=65.6 \mathrm{KN} / \mathrm{m}^{2}$

Skin friction resistances for the sand layer:

$65.6 \times \pi \times 0.60$ dia. $\times 10.0 \mathrm{~m}=1,236.7 \mathrm{KN}$

Total skin friction (Qs) for $600 \mathrm{~mm}$ diameter pile is

$(148.5+1,236.7)=1,385 \mathrm{KN}$

Point Load Capacity

$\sigma$ at tip of pile $=93.7 \mathrm{KN} / \mathrm{m}^{2}$

$\mathrm{Nq}=33.30$ (Terzaghi's shape and depth factor 1943) 
$\mathrm{Qpu}=93.7 \times 33.30=3,120 \mathrm{KN} / \mathrm{m}^{2}$

The limit of maximum value of unit point resistance in sands is $11,000 \mathrm{KN} / \mathrm{m}^{2}$. Hence, the estimated value will be used.

$3,120 \times \pi \times 0.62 / 4=882 \mathrm{KN}$

Ultimate Pile load capacity $\mathrm{Qu}=1,385+882=2,267 \mathrm{KN}$

Allowable pile load capacity $\mathrm{Qa}=\mathrm{Qu} / 2.5=907 \mathrm{KN}$

For $750 \mathrm{~mm}$ Piles

v. Clayey Stratum:

Skin friction resistance for the peat $=\alpha . \mathrm{Cu}$.As

For $600 \mathrm{~mm}$ piles: $0.75 \times 21 \times 0.75 \times \pi \times 5.0 \mathrm{~m}=186 \mathrm{KN}$

vi. Lower Sand Stratum

$\sigma$ at the top of sand stratum $16.08 \times 5.0 \mathrm{~m}=80.4 \mathrm{~N} / \mathrm{m}^{2}$

$\sigma$ at the tip of the pile $\quad 80.4+(12.47-9.81) \times 10.0 \mathrm{~m}=107 \mathrm{KN} / \mathrm{m}^{2}$

$\Sigma$ ave $=(80.4+107) / 2=93.7 \mathrm{KN} / \mathrm{m}^{2}$

Angle of internal friction (for sand) fo $=350$, Hence

$\mathrm{fs}(\mathrm{av})=93.7 \times \tan 350$

$=65.6 \mathrm{KN} / \mathrm{m}^{2}$

Skin friction resistances for the sand layer:

$65.6 \times \pi \times 0.75$ dia. $\times 10.0 \mathrm{~m}=1,546 \mathrm{KN}$

Total skin friction (Qs) for $750 \mathrm{~mm}$ diameter pile is $(186+1,546)=1,732 \mathrm{KN}$

Point Load Capacity

$\sigma$ at tip of pile $=93.7 \mathrm{KN} / \mathrm{m}^{2}$

$\mathrm{Nq}=33.30$ (Terzaghi's shape and depth factor 1943)

$\mathrm{Qpu}=93.7 \times 33.30=3,120 \mathrm{KN} / \mathrm{m}^{2}$

The limit of maximum value of unit point resistance in sands is $11,000 \mathrm{KN} / \mathrm{m}^{2}$. Hence, the estimated value will be used.

$3,120 \times \pi \times 0.752 / 4=1,379 \mathrm{KN}$

Ultimate Pile load capacity $\mathrm{Qu}=1,732+1,379=3,111 \mathrm{KN}$

Allowable pile load capacity $\mathrm{Qa}=\mathrm{Qu} / 2.5=1,244 \mathrm{KN}$

Table 4. Allowable pile load capacities for the piles

\begin{tabular}{lllllll}
\hline Depth $(\mathrm{m})$ & $450 \mathrm{~mm}(\mathrm{KN})$ & & $600 \mathrm{~mm}(\mathrm{KN})$ & \multicolumn{2}{c}{$750 \mathrm{~mm}(\mathrm{KN})$} \\
& Ultimate & Allowable & Ultimate & Allowable & Ultimate & Allowable \\
\hline 12.0 & 1,206 & 482 & 1,818 & 727 & 2,537 & 1,015 \\
15.0 & 1,535 & 614 & 2,267 & 907 & 3,111 & 1,244 \\
\hline
\end{tabular}


Table 5. Laboratory analytical report for sediment samples

\begin{tabular}{|c|c|c|c|c|c|c|c|c|c|c|c|c|c|c|}
\hline S/No & . Parameters & Method & $\begin{array}{l}\text { Sub-sea } \\
\text { Sediment }\end{array}$ & $\begin{array}{l}\text { Sub-sea } \\
\text { t Sediment }\end{array}$ & $\begin{array}{l}\text { Sub-sea } \\
\text { t Sediment }\end{array}$ & $\begin{array}{l}\text { Sub-sea } \\
\text { t Sediment }\end{array}$ & $\begin{array}{l}\text { Sub-sea } \\
\text { t Sediment }\end{array}$ & $\begin{array}{l}\text { Sub-sea } \\
\text { t Sediment }\end{array}$ & $\begin{array}{l}\text { Sub-sea } \\
\text { Sediment }\end{array}$ & $\begin{array}{l}\text { Sub-sea } \\
\text { t Sediment }\end{array}$ & $\begin{array}{l}\text { Sub-sea } \\
\text { t Sediment }\end{array}$ & $\begin{array}{l}\text { Sub-sea } \\
\text { t Sediment }\end{array}$ & $\begin{array}{l}\text { Sub-sea } \\
\text { t Sediment }\end{array}$ & $\begin{array}{l}\text { Sub-sea } \\
\text { t Sediment }\end{array}$ \\
\hline & & & 1 & 2 & 3 & 4 & 5 & 6 & 7 & 8 & 9 & 10 & 11 & 12 \\
\hline 1 & $\mathrm{pH}$ & Meter & 6.89 & 7.13 & 7.04 & 6.68 & 6.84 & 7.03 & 7.11 & 6.87 & 7.01 & 6.79 & 7.12 & 7.19 \\
\hline 2 & $\begin{array}{l}\text { Conductivity } \\
(\mu \mathrm{S} / \mathrm{cm})\end{array}$ & $\begin{array}{l}\text { y ASTM } \\
\text { D1125-14 }\end{array}$ & 3,669 & 4,221 & 5,240 & 4,880 & 5,123 & 4,333 & 4,627 & 3,297 & 3,520 & 6,330 & 4,880 & 3,726 \\
\hline 3 & $\begin{array}{l}\text { Carbonate } \\
(\mathrm{mg} / \mathrm{kg})\end{array}$ & $\begin{array}{l}\text { ASTM } \\
\text { D4373-96 }\end{array}$ & $<1.0$ & 1.0 & 1.0 & 1.0 & 1.0 & 1.0 & 1.0 & 2.0 & 2.0 & 1.0 & 1.0 & 1.0 \\
\hline 4 & $\begin{array}{l}\text { ТРН } \\
(\mathrm{mg} / \mathrm{kg})\end{array}$ & GC-FID & 2.03 & 3.44 & 8.22 & 6.15 & 7.46 & 8.52 & 10.17 & 14.32 & 15.81 & 17.1 & 12.6 & 10.38 \\
\hline 5 & $\begin{array}{l}\text { THC } \\
(\mathrm{mg} / \mathrm{kg})\end{array}$ & $\begin{array}{l}\text { ASTM } \\
5369\end{array}$ & 4.33 & 7.67 & 12 & 13.3 & 8.69 & 8.08 & 9.74 & 18.65 & 15.6 & 13.9 & 22.6 & 18.4 \\
\hline 6 & TOC (\%) & $\begin{array}{l}\text { ASTM } \\
\text { D7573-09 }\end{array}$ & 0.98 & 0.74 & 0.86 & 0.81 & 0.93 & 0.64 & 0.79 & 0.96 & 0.84 & 0.87 & 0.87 & 0.83 \\
\hline 7 & $\begin{array}{l}\text { Cation } \\
\text { Exchange } \\
\text { Carbon } \\
\text { (meqv/mg) }\end{array}$ & $\begin{array}{l}\text { ASTM } \\
\text { D7503-10 }\end{array}$ & 2.8 & 2.6 & 2.8 & 2.6 & 2.5 & 2.6 & 2.7 & 2.7 & 2.9 & 2.7 & 2.9 & 2.9 \\
\hline 8 & $\begin{array}{l}\text { Sulphate } \\
(\mathrm{mg} / \mathrm{kg})\end{array}$ & $\begin{array}{l}\text { ASTM } \\
\text { C1580-09 }\end{array}$ & 75.39 & 71.44 & 90.46 & 88.57 & 100.02 & 91.57 & 93.88 & 94.3 & 95.7 & 82.1 & 145.2 & 123.5 \\
\hline 9 & $\begin{array}{l}\text { Nitrate } \\
(\mathrm{mg} / \mathrm{kg})\end{array}$ & $\begin{array}{l}\text { ASTM } \\
92104, \\
\text { D4646 }\end{array}$ & 5.88 & 4.72 & 4.06 & 5.93 & 6.09 & 7.14 & 7.36 & 7.22 & 8.7 & 8.91 & 3.24 & 5.16 \\
\hline 10 & $\begin{array}{l}\text { Phosphate } \\
(\mathrm{mg} / \mathrm{kg})\end{array}$ & $\begin{array}{l}\text { ASTM } \\
\text { D6146-97 }\end{array}$ & NIL & NIL & NIL & NIL & NIL & NIL & NIL & NIL & NIL & NIL & NIL & NIL \\
\hline 11 & TCC (MPN) & $\begin{array}{l}\text { ASTM } \\
1604\end{array}$ & $5.0 \times 10^{2}$ & $5.29 \times 10^{2}$ & $4.76 \times 10^{3}$ & $4.24 \times 10^{3}$ & $6.83 \times 10^{2}$ & $2.14 \times 10^{3}$ & $4.61 \times 10^{2}$ & $2.11 \times 10^{3}$ & $4.6 \times 10^{2}$ & $7.62 \times 10^{3}$ & $4.38 \times 10^{3}$ & ${ }^{3} 5.11 \times 10^{3}$ \\
\hline
\end{tabular}

Table 6. Correlations with N-values for cohesion-less soils

\begin{tabular}{llll}
\hline N value & $\phi$ & Relative Density $(\%)$ & Description \\
\hline$<4$ & $25-30$ & 0 & Very loose \\
$4-10$ & $27-32$ & 15 & Loose \\
$10-30$ & $30-35$ & 65 & Medium \\
$30-50$ & $35-40$ & 85 & Dense \\
$>50$ & $38-43$ & 100 & Very dense \\
\hline
\end{tabular}

Table 7. Correlations with $\mathrm{N}$-values for cohesive soils

\begin{tabular}{lll}
\hline N value & $\begin{array}{l}\text { Unconfined compression strength } \\
(\mathrm{kPa})\end{array}$ & $\begin{array}{l}\text { Textural } \\
\text { Consistency }\end{array}$ \\
\hline$<2$ & $<25$ & Very soft \\
$2-4$ & $25-40$ & Soft \\
$4-8$ & $40-60$ & Medium-firm \\
$8-16$ & $60-75$ & Stiff \\
$16-32$ & $75-100$ & Very stiff \\
$>32$ & $100-150$ & Hard \\
\hline
\end{tabular}


Table 8. Lateral pressure

\begin{tabular}{|c|c|c|c|c|c|c|c|}
\hline \multirow[t]{4}{*}{$\begin{array}{l}\text { Borehole } \\
\text { No }\end{array}$} & \multirow[t]{2}{*}{ Depth } & \multirow{2}{*}{$\begin{array}{l}\text { Bulk } \\
\text { Unit } \\
\text { Weight }\end{array}$} & \multirow{2}{*}{$\begin{array}{l}\text { Angle of } \\
\text { Friction } \\
\text { Degree }\end{array}$} & $\begin{array}{l}\text { Rankine } \\
\text { Co-efficient }\end{array}$ & $\begin{array}{l}\text { Rankine } \\
\text { Co-efficient }\end{array}$ & \multirow{2}{*}{$\begin{array}{l}\text { Co-efficient of } \\
\text { Earth Pressure } \\
\text { at Rest }\end{array}$} & \multirow[t]{2}{*}{$\begin{array}{l}\text { Poisson } \\
\text { Ratio }\end{array}$} \\
\hline & & & & $\begin{array}{l}\text { of Active } \\
\text { Earth }\end{array}$ & $\begin{array}{l}\text { of Passive } \\
\text { earth }\end{array}$ & & \\
\hline & & $\mathrm{kN} / \mathrm{m}^{3}$ & & Pressure & Pressure & & \\
\hline & (m) & $\gamma$ & & $\mathrm{Ka}$ & $\mathrm{Kp}$ & Ko & $\mu$ \\
\hline $\mathrm{BH}-1$ & 3.00 & 15.90 & 9 & 0.729 & 1.371 & 0.844 & 0.458 \\
\hline BH-7 & 3.00 & 16.16 & 6 & 0.811 & 1.233 & 0.895 & 0.472 \\
\hline BH-8 & 3.00 & 16.03 & 8 & 0.756 & 1.323 & 0.861 & 0.463 \\
\hline BH-10 & 3.00 & 16.23 & 7 & 0.783 & 1.278 & 0.878 & 0.468 \\
\hline BH-12 & 3.00 & 16.08 & 8 & 0.756 & 1.323 & 0.861 & 0.463 \\
\hline
\end{tabular}

Table 9. Undrained triaxial compression tests

\begin{tabular}{|c|c|c|c|c|c|c|c|c|c|}
\hline \multirow[t]{5}{*}{ Borehole } & Depth & \multicolumn{2}{|c|}{ Unit Weights } & \multicolumn{2}{|c|}{ Shear Strength } & \multirow[t]{4}{*}{ Poisson's } & \multirow[t]{4}{*}{ Specific } & \multirow[t]{3}{*}{ Sub-merged } & \multirow[t]{3}{*}{ Normal } \\
\hline & & Bulk Unit & Dry Unit & Undrained & Angle of & & & & \\
\hline & & Weight & Weight & Cohesion & Friction & & & & \\
\hline & & $\gamma$ & $\Gamma$ & $\mathrm{C}$ & & & & $\Delta$ & $\Delta$ \\
\hline & (m). & $\mathrm{KN} / \mathrm{m}^{3}$ & $\mathrm{KN} / \mathrm{m}^{\mathrm{d}}$ & $\mathrm{KN} / \mathrm{m}^{\mathrm{u}}$ & Deg. & $\mu$ & & $\mathrm{KN} / \mathrm{m}^{-3}$ & $\mathrm{KN} / \mathrm{m}^{-2}$ \\
\hline $\mathrm{BH}-1$ & 3.00 & 15.90 & 9.88 & 19 & 9 & 0.458 & 2.67 & 6.09 & 18.27 \\
\hline BH-7 & 3.00 & 16.16 & 10.29 & 21 & 6 & 0.472 & 2.64 & 6.35 & 19.05 \\
\hline BH-8 & 3.00 & 16.03 & 10.08 & 24 & 8 & 0.463 & 2.64 & 6.22 & 18.66 \\
\hline BH-10 & 3.00 & 16.23 & 10.34 & 22 & 7 & 0.468 & 2.63 & 6.42 & 19.26 \\
\hline BH-12 & 3.00 & 16.08 & 10.11 & 20 & 8 & 0.463 & 2.64 & 6.27 & 18.81 \\
\hline
\end{tabular}

Table 10. Atterberg limits

\begin{tabular}{|c|c|c|c|c|c|c|c|}
\hline $\begin{array}{l}\text { Borehole } \\
\text { No }\end{array}$ & Depth & $\begin{array}{l}\text { Moisture } \\
\text { Content } \\
\%\end{array}$ & $\begin{array}{l}\text { Liquid } \\
\text { Limit } \\
\%\end{array}$ & $\begin{array}{l}\text { Plastic } \\
\text { Limit } \\
\%\end{array}$ & $\begin{array}{l}\text { Plasticity } \\
\text { Index } \\
\%\end{array}$ & $\begin{array}{l}\text { Liquidity } \\
\text { Index }\end{array}$ & $\begin{array}{l}\text { USCS } \\
\text { Classification }\end{array}$ \\
\hline BH-1 & 3.00 & 61 & 68 & 36 & 32 & 0.78 & $\mathrm{MH}$ \\
\hline BH-2 & 3.00 & 60 & 66 & 36 & 30 & 0.80 & MH \\
\hline ВH-3 & 3.00 & 57 & 63 & 33 & 30 & 0.80 & MH \\
\hline BH-4 & 1.00 & 62 & 70 & 38 & 32 & 0.75 & $\mathrm{MH}$ \\
\hline BH-5 & 3.00 & 60 & 68 & 34 & 34 & 0.76 & $\mathrm{MH}$ \\
\hline BH-7 & 3.00 & 64 & 71 & 38 & 33 & 0.79 & $\mathrm{MH}$ \\
\hline BH-8 & 3.00 & 59 & 65 & 34 & 31 & 0.81 & $\mathrm{MH}$ \\
\hline BH-10 & 3.00 & 57 & 69 & 36 & 33 & 0.64 & $\mathrm{MH}$ \\
\hline BH-11 & 1.00 & 55 & 66 & 30 & 36 & 0.69 & $\mathrm{MH}$ \\
\hline BH-12 & 3.00 & 59 & 67 & 35 & 32 & 0.75 & MH \\
\hline
\end{tabular}


Table 11. Particle size analysis

\begin{tabular}{|c|c|c|c|c|c|c|c|c|}
\hline & & Moisture & Effective & & & $\begin{array}{l}\text { Coef. of } \\
\text { Uniformity }\end{array}$ & Coef. of Curvature & $\begin{array}{l}\text { Coef. of } \\
\text { Permeability }\end{array}$ \\
\hline BH No & $\begin{array}{l}\text { Depth } \\
\text { (m) }\end{array}$ & $\begin{array}{l}\text { Content } \\
\%\end{array}$ & $\begin{array}{l}\text { Particle } \\
\text { Size } D_{10} \\
(\mathrm{~mm})\end{array}$ & $\begin{array}{l}\text { D30 } \\
(\mathrm{mm})\end{array}$ & $\begin{array}{l}\text { D60 } \\
(\mathrm{mm})\end{array}$ & $\mathrm{Cu}=\mathrm{D}_{60} / \mathrm{D}_{10}$ & $\mathrm{Cc}=\mathrm{D}_{30}{ }^{2} /\left(\mathrm{D}_{10} * \mathrm{D}_{60}\right)$ & $\begin{array}{l}\mathrm{K}=\mathrm{C}^{*} \mathrm{D}_{10}{ }^{2} \\
(\mathrm{~m} / \mathrm{sec})\end{array}$ \\
\hline BH-1 & 6 & 12 & 0.09 & 0.15 & 0.39 & 4.333 & 0.641 & 0.00065 \\
\hline BH-2 & 9 & 17 & 0.09 & 0.15 & 0.39 & 4.333 & 0.641 & 0.00065 \\
\hline BH-3 & 10 & 22 & 0.1 & 0.38 & 0.54 & 5.4 & 2.674 & 0.0008 \\
\hline BH-4 & 5 & 18 & 0.09 & 0.25 & 0.5 & 5.556 & 1.389 & 0.00065 \\
\hline BH-5 & 6 & 21 & 0.096 & 0.3 & 0.5 & 5.208 & 1.875 & 0.00074 \\
\hline \multirow[t]{2}{*}{ BH-6 } & 1 & 25 & 0.075 & 0.12 & 0.425 & 5.667 & 0.452 & 0.00045 \\
\hline & 8 & 16 & 0.08 & 0.15 & 0.38 & 4.75 & 0.74 & 0.00051 \\
\hline BH-7 & 9 & 20 & 0.08 & 0.09 & 0.17 & 2.125 & 0.596 & 0.00051 \\
\hline BH-8 & 15 & 24 & 0.08 & 0.095 & 0.18 & 2.25 & 0.627 & 0.00051 \\
\hline \multirow[t]{2}{*}{ BH-9 } & 3 & 24 & 0.089 & 0.095 & 0.18 & 2.022 & 0.563 & 0.00063 \\
\hline & 12 & 25 & 0.08 & 0.1 & 0.22 & 2.75 & 0.568 & 0.00051 \\
\hline BH-10 & 10 & 27 & 0.08 & 0.099 & 0.18 & 2.25 & 0.681 & 0.00051 \\
\hline BH-11 & 12 & 15 & 0.09 & 0.15 & 0.4 & 4.444 & 0.625 & 0.00065 \\
\hline BH-12 & 9 & 17 & 0.12 & 0.4 & 0.68 & 5.667 & 1.961 & 0.00115 \\
\hline
\end{tabular}

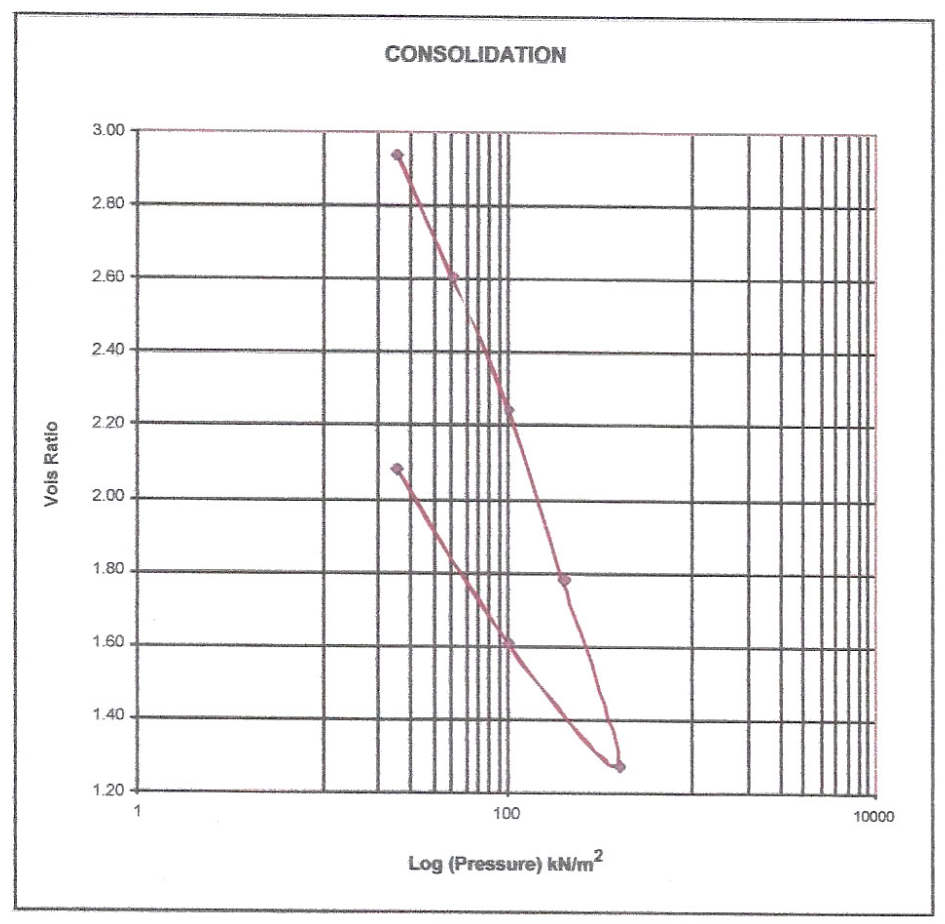

Figure 2. Typical log pressure versus void ratio 


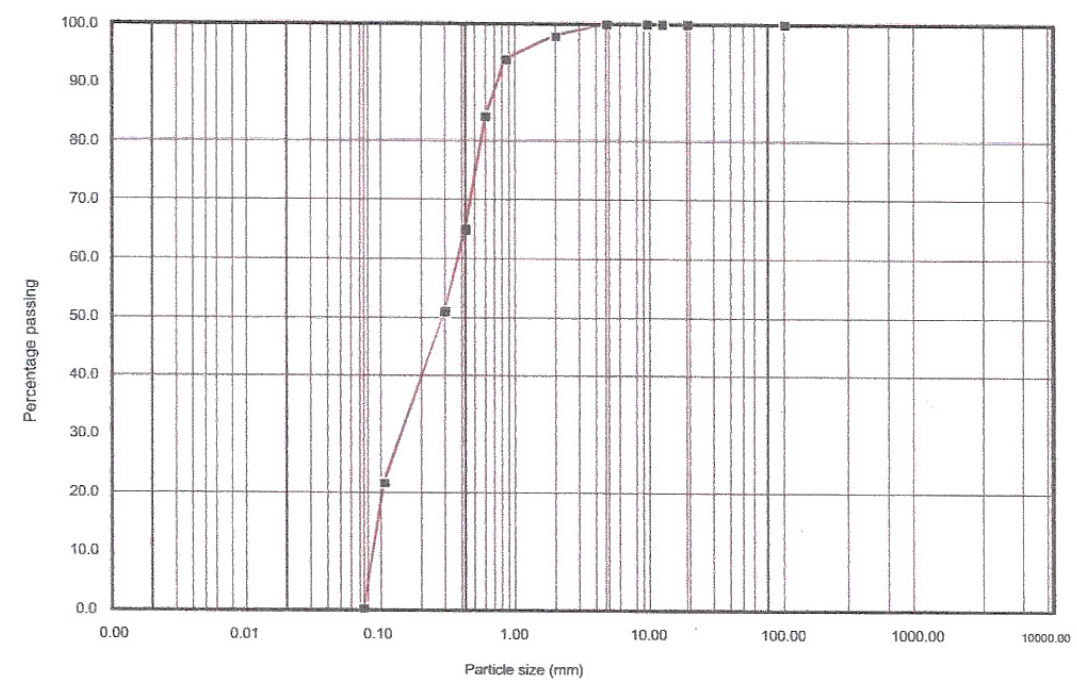

Figure 3. Typical particle size distribution curve

\section{Conclusion}

The soil profiles obtained within the depth explored at the site consist essentially of two soil zones. They are very soft silty clays and medium dense sands . This study shows that within the depths bored, a relatively high deposit of clay overlies the boreholes from the river-bed to average depth of $3.0 \mathrm{~m}$. In BHs 8, 10, 11 and 12, the clay extends beyond $3.0 \mathrm{~m}$ thickness with varying depths ranging from $5.0 \mathrm{~m}$ to $8.0 \mathrm{~m}$. However, prevalent deposits of sand underlie the clay to the end of the boreholes. In BHs 6 and 9, the entire holes are characterized by huge deposits of sand formation. All the boreholes have potentials for sand borrows. Notably, the sandy formation exhibited appreciable SPT blows indicating sands of medium densification. Ultimate pile load carrying capacity was estimated for $450 \mathrm{~mm}, 600 \mathrm{~mm}$ and $750 \mathrm{~mm}$ axially loaded straight shafted pile terminated at $-12.0 \mathrm{~m}$ and $-15.0 \mathrm{~m}$ in the sand stratum. Sand volume estimate was limited to $-10.50 \mathrm{~m}$ from the river-bed. Scooping of the clayey materials is required to expose the sand deposits. Appropriate dredging operation should be limited to the area covered by the survey.

\section{Acknowledgement}

The author thanks Earthlog Geoservices Limited for the opportunity to participate in the study. Also appreciate the anonymous reviewers for their inputs and useful comments that generally improved the quality of the paper.

\section{References}

Adegoke, O. S., Jeje, L. K., Durotoye, B., Adeleye, D. R., \& Ebukanson, E. E. (1980). The Geomorphology and Aspects of Sedimentology of Coastal Region of Western Nigeria. Journal of Mining Geology, 17, 217-223.

Adepelumi, A., Olorunfemi, M., Falebita, D., \& Bayowa, O. (2009). Structural mapping of coastal plain sands using engineering geophysical technique: Lagos Nigeria case study. Natural Science, 1, 2-9. https://doi.org/10.4236/ns.2009.11002

Adepelumi, A. A., \& Olorunfemi, M. O. (2000). Engineering geological and geophysical investigation investigation of the reclaimed Lekki Peninsula, Lagos, Southwest Nigeria. Bulletin of Engineering, Geology and the Environment, 58, 125-132. https://doi.org/10.1007/s100640050006

Adeyemi, G. O., \& Osammor, J. (2000). In-situ Geotechnical Investigation of Soils in Southtern Nigeria. Journal of Mining and Geololgy, 37(1), 69-76.

Ameh, P., Igwe, O., Abdullateef, L., Mustapha, A., Isa, A., \& Zakariyau, K. K. (2018). Assessment of the Implications of Geotechnical Properties of Soils in Otukpa Area of Ogbadibo LGA, Benue State, Nigeria. Journal of Geosciences and Geomatics, 6(1), 1-11. https://doi.org/10.12691/jgg-6-1-1

Bell, F. G. (2011). Eng. Geol. (2nd ed., p. 311). Elsevier publishers, India.

Bell, F. G., Cripps, J. C., \& Culshaw, M. G. (1990). Field Testing Methods for Engineering Geological Investigations Geological Society, London, Engineering Geology Special Publications, 6, 3-20. https://doi.org/10.1144/GSL.ENG.1990.006.01.01 
Bolton, M. D. (1981). Limit State Design in geotechnical Engineering. Ground Engineering, 14(6), 39-46.

Braja, M. D. (2005). Fundamentals of geotechnical Engineering (2nd ed.). Quebecor Printers.

Casagrande, A. (1932). Research on the Atterberg limits of soils. Public Roads, 13(8), 121-136.

Clayton, C. R. I., Mattew, M. C., \& Simons, N. E. (1996). Site investigation (2nd ed., p. 318). Blackwell scientific publishers, Oxford.

Ejembi, S. (2016). Ten Tragic Building Collapses in Nigeria. Retrieved from http://www.punchng.com/ 10-tragic-building-collapses-in-nigeria/

Johnson, R. B., \& Degraff, J. V. (1988). Principles of Engineering Geology. John Willey and Sons, New York.

Kogbe, C. A., Ajakaiye, D. E., \& Matheis, G (1983). Confirmations of a rift structure along the Mid-Niger valley, Nigeria. J. Afr. Earth Sci, 6, 234-242. https://doi.org/10.1016/0899-5362(83)90004-0

Lekmang, I. C., Daku, S. S., Yenne, E. Y., Wazoh, H. N., \& Goyit, M. P. (2016). Geotechnical investigations for infrastructural development: A case study of Daki Biyu District, Federal Capital Territory, Abuja, Central Nigeria. Journal of Geology and Mining Research, 8(3), 28-39. https://doi.org/10.5897/JGMR2016.0248

Oteri A. U., \& Atolagbe, F. P. (2003). Saltwater Intrusion into Coastal Aquifers in Nigeria. Paper presented at The Second International Conference on Saltwater Intrusion and Coastal Aquifers - Monitoring, Modeling, and Management.

Sanglerat, G. (1972). The Penetrometer and soil Exploration. Elsevier, Amsterdam. https://doi.org/10.1097/ 00010694-197308000-00009

Terzaghi, K. (1943). Theoretical Soil Mechanics (p. 510). John Willey and Sons, New York. https://doi.org/10.1002/9780470172766

Terzaghi, K., \& Peck, R. B. (1967). Soil Mechanics in Engineering Practice (p. 729). John Willey and Sons, New York.

Warmate, T., \& Nwankwoala, H. O. (2018). Geotechincal Indications and Shallow Bearing Capacity Analysis Within Lekki Peninsula, Lagos Using Direct Shear Analysis. Int Arch Env Ear Sci, IAEES-104.

\section{Copyrights}

Copyright for this article is retained by the author(s), with first publication rights granted to the journal.

This is an open-access article distributed under the terms and conditions of the Creative Commons Attribution license (http://creativecommons.org/licenses/by/4.0/). 